\title{
Episodes from the Continuous Search for Solutions against Downy Mildew Diseases
}

\author{
Clemens Lamberth* \\ SISF-SCS Distinguished Investigator Award 2018
}

\begin{abstract}
Discovery background, lead optimization pathways, synthesis and structure-activity relationships of three different research projects searching for new active ingredients against downy mildew diseases are reported. These case studies, on which the author worked in three different decades in the research departments of Syngenta Crop Protection AG and its legacy company Novartis Crop Protection AG deal with inhibitors of cellulose synthase, tubulin polymerization and oxysterol-binding protein. Rarely used reactions, which have been applied within these projects, such as Seebach's variation of the Passerini reaction, the Bogert quinazoline synthesis and the carbonyldiimidazole-mediated Lossen rearrangement give proof of the significance of synthetic organic chemistry for modern crop protection.
\end{abstract}

Keywords: Agrochemical · Crop Protection · Fungicide · Mandipropamid · Oomycete

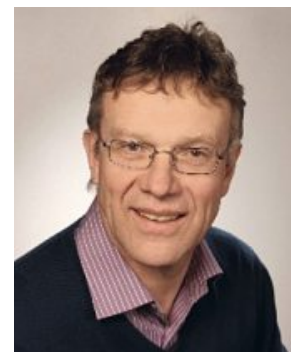

Clemens Lamberth was born in 1961 and studied chemistry at the Technical University of Darmstadt, where he obtained his $\mathrm{PhD}$ under the supervision of Prof. Bernd Giese in 1990. Subsequently he spent one and a half years in the group of Prof. Mark Bednarski at the University of California at Berkeley. In 1992 he joined the agrochemical research department of Sandoz Agro AG, which is one of the legacy companies of Syngenta Crop Protection AG, the company he is working for now. For the past 27 years Clemens Lamberth has specialized on fungicide chemistry. He is the author of more than 75 publications, 15 book chapters and 100 patent applications and the co-editor of the two books 'Bioactive Heterocyclic Compound Classes' and 'Bioactive Carboxylic Compound Classes'. Clemens Lamberth played a key role in the invention of the fungicide mandipropamid (Revus ${ }^{\mathrm{TM}}$, Pergado ${ }^{\mathrm{TM}}$ ), still the gold standard for the control of downy mildew diseases.

\section{Introduction: The Oomycetes Pathogens, Causal Agents of Downy Mildew Diseases}

The oomycetes are a family of more than 800 different funguslike eukaryotic microorganisms, which are more related to algae than to fungi and which include some of the most devastating plant pathogens known. ${ }^{[1-3]}$ Some of these filamentous protists live in aquatic, others in terrestrial biotopes, some are saprophytes (feeding on dead material), others are parasites. Despite this ecological diversity, the oomycetes are a well-defined unit of high physiological and biochemical uniformity. Their cell walls consist mainly of cellulose, glucans and hydroxyproline instead of chitin, which is common in most other phytopathogenic fungi from the families of ascomycetes, basidiomycetes and deuteromycetes. In addition, the life cycle of oomycetes is primarily diploid and not haploid as in true fungi. Parasitic members of the oomycetes class are for instance Peronospora tabacina, causal agent of tobacco blue mold, and Pythium ultimum, causal agent of the damping-off and root rot diseases, but the economically most important diseases are due to Plasmopara viticola, causal agent of grape downy mildew, and Phytophthora infestans, causal agent of potato and tomato late blight. The latter pathogen caused the complete devastation of the Irish potato fields in the years 1845 to 1852 . The dependence of the rural population on the potato harvest and the non-existence of chemical crop protection resulted in a famine of unbelievable dimensions, during which one million Irish people starved to death and two million emigrated to North America. ${ }^{[4,5]}$ Seventy years later, first fungicides such as the copper-based Bordeaux mixture had been invented already, but in the middle of World War I all copper was required for the production of ammunition and therefore 400,000 people died from hunger in the German turnip winter 1916/17 after another major outbreak of Phytophthora infestans. ${ }^{[6]}$ Even today, especially in years with summers of high humidity, a loss of at least $15 \%$ in potato and grape yield has to be expected due to oomycetes infestation, although meanwhile there is fortunately a whole arsenal of well-established oomycetes fungicides on the market. The pressure especially on older products because of increased resistance, expired patent protection and regulatory challenges regarding regular re-registrations, ensures a constant need for the discovery of new classes of anti-oomycete active ingredients with high activity, a favourable environmental profile and preferably also a novel mode of action. In this review article three different oomycetes projects will be presented, on which the author has worked in the research departments of Syngenta Crop Protection AG and its legacy company Novartis Crop Protection AG within three different decades.

\section{1990s: Inhibitors of Cellulose Synthase}

In the 1990s, the search for new compounds with anti-oomycetes activity had focused on $\mathrm{N}$-carbamoylvalinamides. With iprovalicarb ${ }^{[7]}$ and benthiavalicarb, ${ }^{[8]}$ two specific amino acid amides with an 1-aryl- or heteroarylethylamine moiety had already entered development at competitor companies at the time of our 
project start. We chose the valinamide 1 with a 2-phenethylamine portion, which had been patented by American Cyanamid (today part of BASF), ${ }^{[9]}$ as our lead structure because of the less crowded patent situation. We had some in-house experience with sulfonylated amino acid derivatives and therefore decided to replace the carbamate function of $\mathbf{1}$ by a sulfonamide. Actually, this transformation successfully enhanced the weak fungicidal activity of $\mathbf{1}$ multifold, but only after we found out that in addition the short methoxy group in the para-position of the phenyl ring had to be exchanged by a much longer phenylpropargyloxy side chain. The resulting $N$-sulfonylvalinamide 2 was very active against oomycetes pathogens even under field conditions, but not on the level of a commercial standard. ${ }^{[10]}$ During the attempt to further increase the biological efficacy, many different molecular manipulations were tried, but in the end only the phenyl shift from the terminal position of the amine part to the central carbon atom of the amino acid, turning the valinamide 2 into the nonproteogenic phenylglycinamide $\mathbf{3}$, gave satisfying results. ${ }^{[10,11]}$ Approximately at the same time we realized that Agrevo (today part of Bayer) had found quite similar mandelamides, such as SX $623509(4),{ }^{[12,13]}$ which were only moderately active against downy mildew diseases. Convinced that the propargyloxy group in our phenylglycinamide $\mathbf{3}$ was responsible for at least part of its excellent fungicidal efficacy, we applied propargylation also to the field of mandelamides. As a matter of fact, the resulting mandelamide 5 was clearly more active than the non-proparglyated lead compound $\mathbf{4}$, but still not on the potency level we wanted to achieve. ${ }^{[11,14]}$ The introduction of a second propargyl ether into the mandelic acid moiety finally delivered the desired step change in fungicidal activity. Mandipropamid (6) possesses a potency level against $P$. infestans, $P$. viticola and Pseudoperonospora cubensis, causal agent of cucurbits downy mildew, which at that time was unseen before and still is unrivalled by almost all other commercial products. Mandipropamid inhibits the cell-wall biosynthesis by targeting the cellulose synthase 3 isoform and belongs together with the above-mentioned valinamides to the oomycete-selective fungicide class of Carboxylic Acid Amides (CAA fungicides). ${ }^{[15,16]}$ It is highly effective in preventing spore germination, but also inhibits mycelial growth and sporulation by binding rapidly and tightly to the wax layer of the leaf surface and providing there a rain-fast and long-lasting barrier against infections. (Scheme 1).
The synthesis of mandipropamid's phenethylamine moiety starts from vanillin (7), which is converted into its cyanohydrine $\mathbf{8}$. Subsequent catalytic hydrogenation delivers 3-O-methyldopamine (9, also called 3-methoxytyramine), a very important amine building block for different synthesis strategies towards mandipropamid. In the beginning of our mandelamide exploration, we chose a Passerini-type approach as major preparation route as it allowed us the highest variability in scoping different substituents and scaffold variations especially in the mandelic acid portion. Therefore 3-O-methyldopamine $(\mathbf{9})$ was converted into the stable and odourless isocyanide $\mathbf{1 2}$ by $\mathrm{N}$-formylation, $\mathrm{O}$-propargylation and dehydration. Hereby, the formyl group serves as protecting group for the amine function during the alkylation of the phenol and also as precursor for the formation of the isocyanide function. The isocyanide $\mathbf{1 2}$ was then directly transformed by Seebach's variation of the Passerini reaction into the mandelamide 13. The classical Passerini reaction is a three-component condensation, in which a carbonyl, a carboxylic acid and an isocyanide react to an $\alpha$-acyloxycarboxamide. ${ }^{[17,18]}$ An elegant pathway leading directly to a $\alpha$-hydroxycarboxamide is Seebach's variation, which applies Lewis acids instead of carboxylic acids. ${ }^{[19,20]}$ The introduction of a second propargyl function into the mandelic acid part of $\mathbf{1 3}$ directly delivers mandipropamid (6). ${ }^{[11,14]}$ Seebach's variation of the Passerini reaction, the transformation from 12 to $\mathbf{1 3}$, was a perfect tool for exploring the ideal molecular requirements in the acid part of the newly discovered $\alpha$-alkoxycarboxyamides, as it worked not only with many differently substituted benzaldehydes, ${ }^{[11,14]}$ but also with heterocyclic and aliphatic aldehydes. ${ }^{[1,21]}$ However, this titanium(IV) chloride-mediated transformation at low temperatures was not viable for any large-scale production. Therefore we were also looking for a scalable process for mandipropamid (6). Its acid portion can be much more efficiently prepared by converting 4-chlorobenzaldhyde (16) into the corresponding cyanohydrin $\mathbf{1 7}$, which is then further reacted by acidic hydrolysis to 4-chloromandelic acid (18). This $\alpha$-hydroxycarboxylic acid was then transformed with acetone under acidic conditions into the acetonide $\mathbf{1 5}$, which delivers upon ring opening with 3- $O$-methyldopamine (9) the mandelamide 14, bearing both an alcoholic and a phenolic hydroxyl function. Both $\mathrm{OH}$ groups were then simultaneously alkylated with propargyl bromide under phase-transfer conditions to obtain mandipropamide (6). ${ }^{[15]}$ This means that mandipropamid can be very efficiently synthesized via the cyanohydrin formation of two inex-
Scheme 1. Invention pathway of mandipropamid (6).

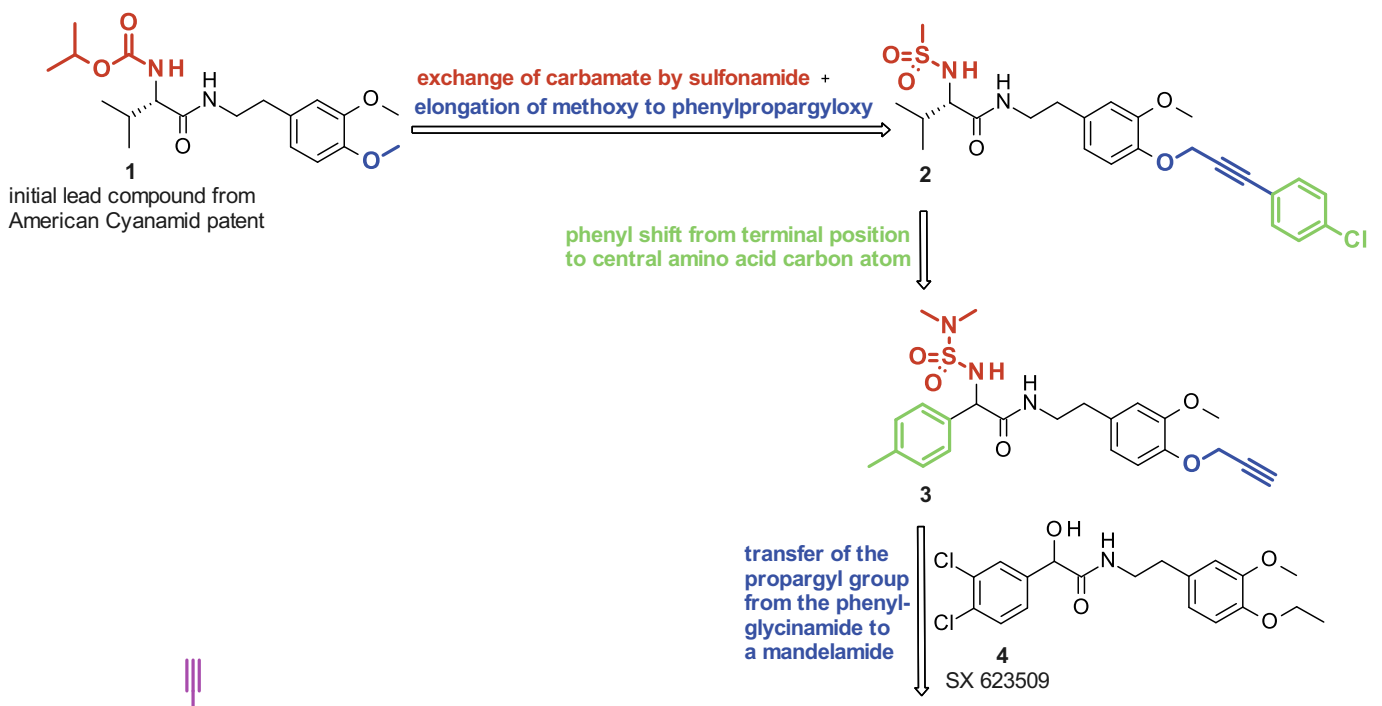

introduction of a second propargyl function

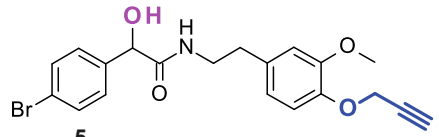


pensive aldehydes which are vanillin (7) and 4-chlorobenzaldehyde (16), one of the cyanohydrins delivering an $\alpha$-hydroxycarboxylic acid, the other one a phenethylamine (Scheme 2).

During the optimization of the alkoxy substituent in the benzylic position of the mandelamides, we found to our big surprise that besides the methyl, ethyl, allyl and propargyl groups, many other alkyl groups could not be introduced by the above-described standard, base-mediated nucleophilic substitution. For instance all attempts to convert the mandelamide $\mathbf{1 3}$ into the $n$-propyl ether failed using propyl bromide or propyl iodide in connection with many different bases in solution or under phase-transfer conditions. Of course the biological performance of such close analogs of mandipropamid was highly desirable to obtain, therefore we had to work out a completely different synthesis strategy to alkyl mandelamide ethers. The $N$-formylated phenethylamine $\mathbf{1 1}$ was deprotected under acidic conditions to obtain 3-O-methyl-4- $O$-propargyldopamine (19). The transformation of this phenethylamine derivative with benzoyl peroxide delivered the $O$-benzoylated hydroxylamine derivative
20, which subsequently was acylated with 4-chlorophenylacetic acid to obtain 21. Debenzoylation delivered the hydroxamic acid 22, which was converted into the $N$-mesyloxy amide 23. This reactive intermediate cyclizes upon treatment with triethyl amine via 1,3-elimination to the even less stable $\alpha$-lactam 24, which opens to the ion pair intermediate 25. [22] Upon treatment with $n$-propanol, this highly reactive species delivers the desired $O$-alkylated mandelamide 26 (Scheme 3). ${ }^{[14]}$

As mandipropamid (6) bears a chiral center, we had also been interested in synthetic access to enantiopure mandelamides. With a highly stereoselective Passerini reaction based on a chiral-pool carboxylic (galacturonic) acid component ${ }^{[23]}$ and a rhodium-catalyzed homogeneous hydrogenation of phenylglyoxylic amides with chiral diphosphine ligands ${ }^{[24]}$ we found two novel methods for the asymmetric synthesis of mandelamides. However, none of the two enantiomers, when used alone, offers a biological advantage over the mixture, therefore mandipropamid has been commercialized as racemate.

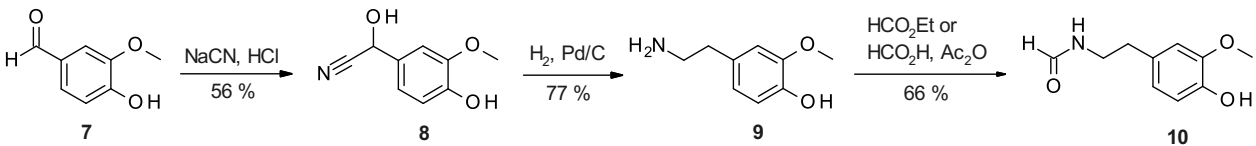

$$
\begin{aligned}
& \begin{array}{l}
\mathrm{HC}=\mathrm{CCH}_{2} \mathrm{Br}, \\
\mathrm{NaOMe}
\end{array} 91 \%
\end{aligned}
$$

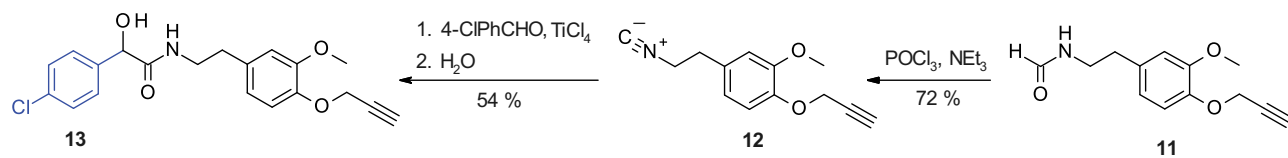

$\begin{aligned} & \mathrm{HC} \equiv \mathrm{CCH}_{2} \mathrm{Br}, \\ & \mathrm{NaOH}, \mathrm{TBAB}\end{aligned} \mid 79 \%$
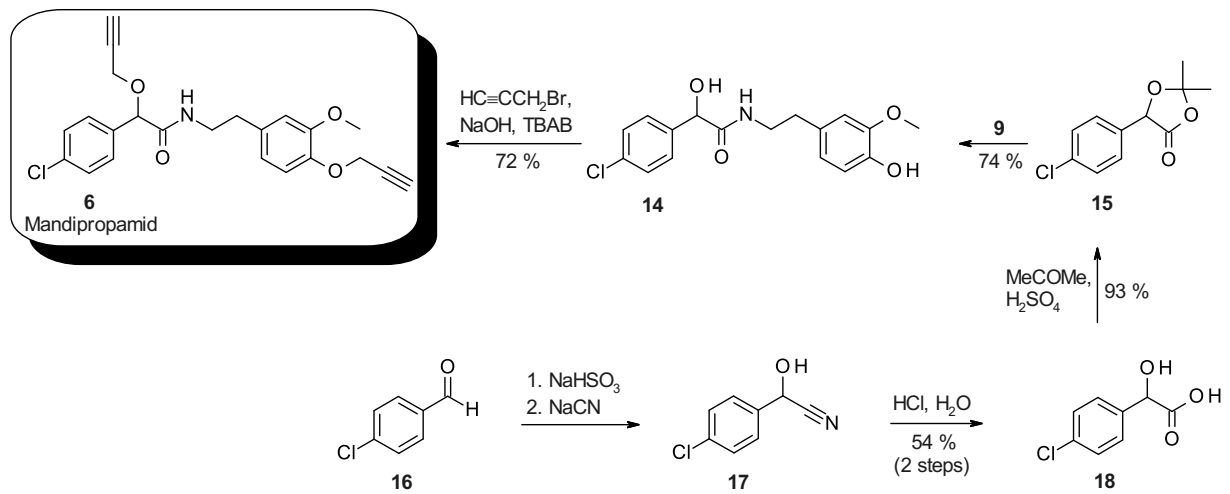<smiles>C#CCOc1ccc(CCNC(=O)O)cc1OC</smiles><smiles>CC#CCOc1ccc(CCN)cc1OC</smiles><smiles>C#CCOc1ccc(CCNOC(=O)c2ccccc2)cc1OC</smiles>

20 $\underset{\mathrm{BOP}, \mathrm{iPrNEt}}{4-\mathrm{CPHCH}_{2} \mathrm{CO}_{2} \mathrm{H},} \mid 64 \%$

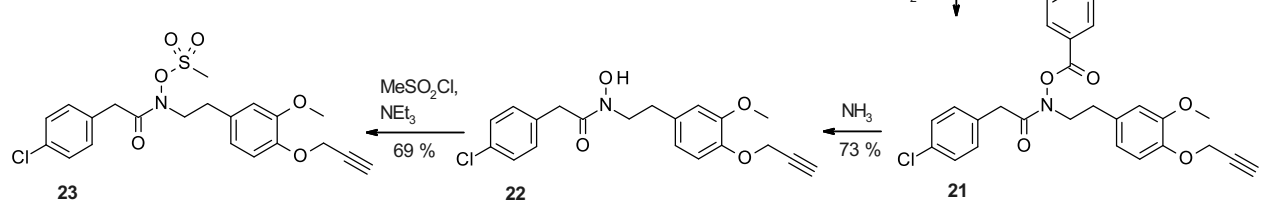<smiles></smiles><smiles>C#CCOc1ccc(CCNC(=O)C(OCCC)c2ccc(OCC#CCOc3ccc(/C=C/N=[N+]([O-])[O-])cc3OC)cc2)cc1OC</smiles>

Scheme 3. Synthesis of the mandelamide fungicide 26 .
Scheme 2. Synthesis of mandi propamid (6). 
During the optimization of the mandelamide class, it soon became clear that both propargyl groups have a huge impact on the fungicidal activity. Table 1 shows the influence of the substituent of the hydroxyl group in the mandelic acid moiety on the activity against the oomycetes pathogens Phytophthora infestans and Plasmopara viticola. The alkylation of the free hydroxyl function (entry 1) in the mandelamide $\mathbf{1 3}$ generally leads to an increase in fungicidal activity. Especially $\mathrm{C}_{2}$ (e.g. entry 3 ) and $\mathrm{C}_{3}$ (e.g. entry 6) units seem to possess the best potential. A comparison between the propargylated mandelamide (entry 6) and its allyl (entry 5) and $n$-propyl (entry 4) analogs reveals that the fungicidal activity increases with enhanced degree of unsaturation in the linear $\mathrm{C}_{3}$ chain. Branching (entry 7) or elongation (entry 8 ) of the propargyl group reduces the anti-oomycetes activity. All in all it can be stated that the propargyl function delivers an unrivalled level of efficacy against the two most important oomycetes diseases (Table 1). ${ }^{[14]}$
The structure-activity relationship situation of the phenol function in the para-position of the phenethylamine side chain is very similar to the above discussed benzylic position of the mandelic acid moiety. The very poor fungicidal activity of the free phenol (entry 1) can be improved by alkylation, also here propargylation (entry 4) leads by far to the best result. And again the introduction of small alkyl groups into different positions of the propargyl group (entries 5 and 6) reduces the fungicidal activity. ${ }^{[14]}$ The outstanding significance of both propargyl groups of mandipropamid (6) for its reliable performance against devastating oomycetes pathogens even under high disease pressure is reflected in the middle part 'diprop' of this active ingredient's common name, which stands for the dipropargylation (Table 2).

\section{2000s: Inhibitors of Tubulin Polymerization}

In the beginning of the first decade of this century, when mandipropamid (6) had already been promoted to development, we

Table 1. Influence of the hydroxyl substituent in the mandelic acid moiety of mandelamides on the fungicidal activity<smiles>[R]OC(C(=O)NCCc1ccc(OCC#C)c(OC)c1)c1ccc(Cl)cc1</smiles>

\begin{tabular}{|c|c|c|c|}
\hline Entry & $\mathbf{R}$ & $\begin{array}{l}\text { Phytophthora infestans } \\
\text { (tomato late blight) } \\
{\left[\mathrm{EC}_{80} \text { in } \mathrm{mg} \mathrm{L}^{-1}\right]}\end{array}$ & $\begin{array}{c}\text { Plasmopara viticola } \\
\text { (grape downy mildew) } \\
{\left[\mathrm{EC}_{80} \text { in } \mathrm{mg} \mathrm{L}^{-1}\right]}\end{array}$ \\
\hline $1(\mathbf{1 3})$ & $\mathbf{H}$ & 34.6 & 10.4 \\
\hline 2 & $\mathrm{CH}_{3}$ & 9.7 & 3.5 \\
\hline 3 & $\mathrm{CH}_{2} \mathrm{CH}_{3}$ & 4.6 & 2.0 \\
\hline 4 & $\mathrm{CH}_{2} \mathrm{CH}_{2} \mathrm{CH}_{3}$ & 5.4 & 31.0 \\
\hline 5 & $\mathrm{CH}_{2} \mathrm{CH}=\mathrm{CH}_{2}$ & 44.1 & 18.6 \\
\hline $6(6)$ & $\mathrm{CH}_{2} \mathrm{C} \equiv \mathrm{CH}$ & 0.1 & 1.2 \\
\hline 7 & $\mathrm{C}\left(\mathrm{CH}_{3}\right)_{2} \mathrm{C} \equiv \mathrm{CH}$ & 4.9 & 3.5 \\
\hline 8 & $\mathrm{CH}_{2} \mathrm{C} \equiv \mathrm{CCH}_{3}$ & 18.3 & 14.0 \\
\hline
\end{tabular}

Table 2. Influence of the hydroxy substituent in the phenethylamine moiety of mandelamides on the fungicidal activity<smiles>[R]Oc1ccc(CCNC(=O)C(OCC#C)c2ccc(Cl)cc2)cc1OC</smiles>

\begin{tabular}{|c|c|c|c|}
\hline Entry & $\mathbf{R}$ & $\begin{array}{l}\text { Phytophthora infestans } \\
\text { (tomato late blight) } \\
{\left[\mathrm{EC}_{80} \text { in } \mathrm{mg} \mathrm{L}^{-1}\right]}\end{array}$ & $\begin{array}{l}\text { Plasmopara viticola } \\
\text { (grape downy mildew) } \\
{\left[\mathrm{EC}_{80} \text { in } \mathrm{mg} \mathrm{L}^{-1}\right]}\end{array}$ \\
\hline 1 & $\mathbf{H}$ & 45.6 & 100.5 \\
\hline 2 & $\mathrm{CH}_{3}$ & 4.2 & 2.0 \\
\hline 3 & $\mathrm{CH}_{2} \mathrm{CH}_{3}$ & 3.5 & 1.8 \\
\hline $4(6)$ & $\mathrm{CH}_{2} \mathrm{C} \equiv \mathrm{CH}$ & 0.1 & 1.2 \\
\hline 5 & $\mathrm{CH}\left(\mathrm{CH}_{3}\right) \mathrm{C} \equiv \mathrm{CH}$ & 8.1 & 51.7 \\
\hline 6 & $\mathrm{CH}_{2} \mathrm{C} \equiv \mathrm{CCH}_{2} \mathrm{CH}_{3}$ & 3.9 & 13.4 \\
\hline 7 & $\mathrm{CH}_{2} \mathrm{C}_{6} \mathrm{H}_{5}$ & 25.5 & 19.7 \\
\hline
\end{tabular}


obtained a new opportunity for fungicide derivatization via crossindication screening. The glyoxylic acid acetal derivative 27 belonged to a herbicide project, but showed surprisingly some weak, but interesting fungicidal activity, although still possessing a lot of damaging effects to the crop plants. During our hit-to-lead optimization this phytotoxicity could be completely removed and in parallel the fungicidal efficacy enhanced by enlarging the dichlorophenyl end group of $\mathbf{2 7}$ to a bromoquinoline and by simultaneous replacement of the acetal by a mixed $O, S$-acetal.[25] The resulting quinolin-6-yloxyacetamide $\mathbf{2 8}$ showed promising control of a broad range of especially cereal pathogens even under field conditions, but seemed to have lost most of the potency against oomycetes species, which we had seen as a specific potential in the lead compound 27. Amongst several different synthesis directions, during which we varied different parts of $\mathbf{2 8},{ }^{[26-28]}$ finally it was the fine-tuning of physico-chemical properties of the quinoline portion of $\mathbf{2 8}$, resulting in the close analogs $\mathbf{2 9}$ and $\mathbf{3 0}$, which brought back the potency against the most important oomycetes diseases. ${ }^{[29]}$ The fungicidal activity of all of these compounds is due to their ability to inhibit the fungal tubulin polymerization by binding to the colchicine site, leading to microtubule destabilization (Scheme 4). ${ }^{\text {[30] }}$

The synthesis of the quinoline-based broad-spectrum fungicide 28 starts with the Skraup-type ring closure reaction of 4-methoxy-2-methylaniline (31) with 2,2,3-tribromopropanal to deliver the 3-bromoquinoline derivative 32. 2,2,3-Tribromopropanal, available in only one step by bromination of acrolein, had been described only twice in the 1950s as a three-carbon synthon for the Skraup-cyclization of anilines, ${ }^{[31,32]}$ simultaneously achieving ring closure and introduction of the desired bromine in position 3 of the quinoline, before we re-discovered this forgotten reagent fifty years later for the same purpose, which enabled us the synthesis of several different novel tri- and tetrasubstituted quinoline building blocks. ${ }^{[33]}$ Ether cleavage of the 6-methoxyquinoline derivative 32 led to 3-bromo-8-methylquinolin-6-ol (33), which was alkylated with methyl 2-chloro-2-(methylsulfanyl)acetate to deliver the desired mixed $O, S$-acetal derivative 34. Saponification of its ester function delivers the carboxylic acid 35, which was converted into the desired quinolin-6-yloxyacetamide 28 by amidation with 2-methylpent-3-yn-2-amine under peptide coupling conditions (Scheme 5). [25]

The Skraup-type approach used for the synthesis of $\mathbf{2 8}$ is not applicable to the quinazoline ring system of the more polar analog 29, because instead of the bromo-substituted ring carbon in position 3 a ring nitrogen has to be introduced into the heterobicyclic scaffold. Therefore we decided to apply the Bogert quinazoline synthesis, as it allowed us to obtain the required intermediate 6-hydroxyquinazoline (39) from inexpensive 3-hydroxybenzaldehyde (36). This special ring condensation method, which was developed by Marston Bogert in the $1930 \mathrm{~s}^{[34,35]}$ and which is not found often in the literature, starts with the regioselective nitration of 36. The resulting disubstituted benzaldehyde $\mathbf{3 7}$ is then converted with formamide under a hydrogen chloride gas stream into the $N, N^{\prime}$-diformylated aminal $\mathbf{3 8}$, which undergoes reductive cyclization by treatment with zinc in acetic acid to deliver directly the desired building block 39. In analogy to the above described synthesis sequence $\mathbf{3 3} \rightarrow \mathbf{2 8}$, the hydroxyl function of $\mathbf{3 9}$ was then alkylated with methyl 2-chloro-2-(methylsulfanyl)acetate, the ester function of $\mathbf{4 0}$ was hydrolytically cleaved and the resulting carboxylic acid $\mathbf{4 1}$ converted into the target product $\mathbf{2 9}$, which is a quinazoline analog of the quinoline derivative $\mathbf{2 8}$ (Scheme 6). [29]

For the synthesis of the benzothiazole-based tubulin polymerization inhibitor 30 we chose 2-chloro-4-methoxyaniline (42) as starting material, which could be cyclized to the 2-aminobenzothiazole derivative $\mathbf{4 3}$ upon treatment with potassium thiocyanate and bromine. This well-known 2-aminobenzothiazole synthesis proceeds via an ortho-thiocyanatoaniline intermediate, which undergoes ring closure by reaction with bromine. ${ }^{[36,37]}$ For the following deamination we applied Chedekel's conditions with sodium nitrite and phosphinic acid. ${ }^{[38,39]}$ The ether cleavage of the resulting methoxy-substituted benzothiazole $\mathbf{4 4}$ delivered the desired 4-chloro-6-hydroxybenzothiazole 45. The finalization of the synthesis is achieved by using the same last three steps as already applied for the preparation of $\mathbf{2 8}$ and $\mathbf{2 9}$ in Schemes 5 and 6 , which are alkylation of the phenol function to 46, ester saponification to 47 and amide coupling, delivering the benzothiazole analog $\mathbf{3 0}$ of the quinoline derivative $\mathbf{2 8}$ (Scheme 7). ${ }^{\text {[29] }}$

Although several of the quinolin-6-yloxyacetamides such as 28 showed mediocre activity against the foliar diseases potato late blight and grape downy mildew, good in vivo activity against the

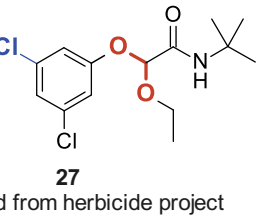

initial lead from herbicide project

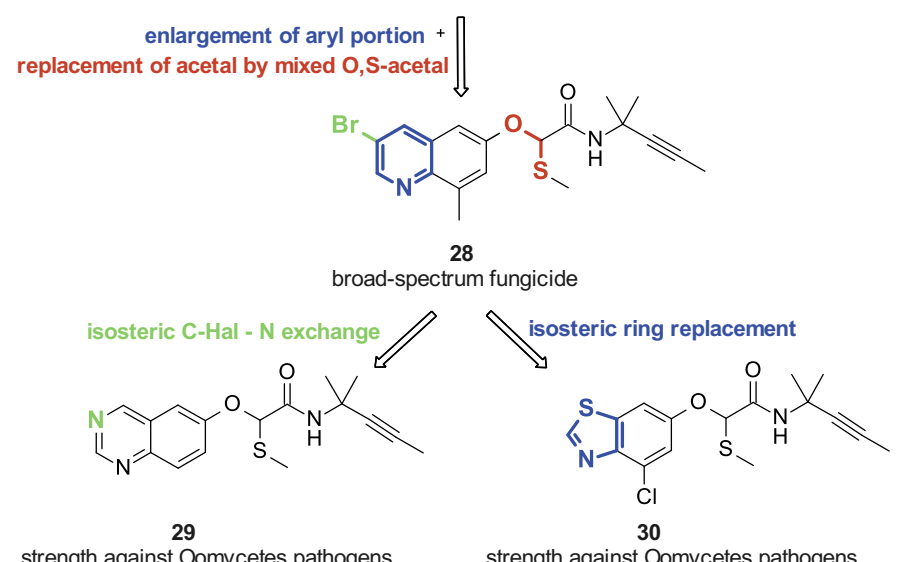

strength against Oomycetes pathogens

Scheme 4. Invention pathway of the experimental oomycetes fungicides 29 and 30.

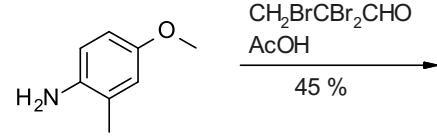

31

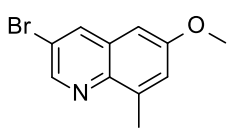

32

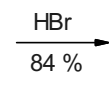<smiles>Cc1cc(O)cc2cc(Br)cnc12</smiles>

33

$$
\begin{aligned}
& \mathrm{ClCH}(\mathrm{SMe}) \mathrm{CO}_{2} \mathrm{Me}, \\
& \mathrm{K}_{2} \mathrm{CO}_{3}
\end{aligned}
$$

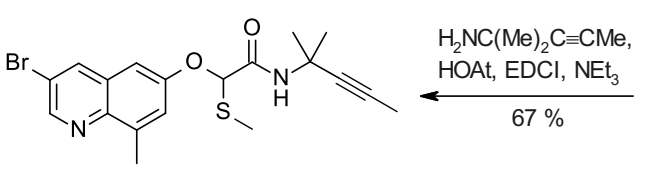

28

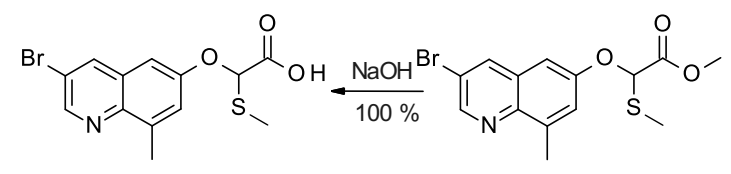

35
Scheme 5. Synthesis of the quinoline-based broad-spectrum fungicide 28. 
Scheme 6. Synthesis of the quinazoline-based oomycetes fungicide 29 .
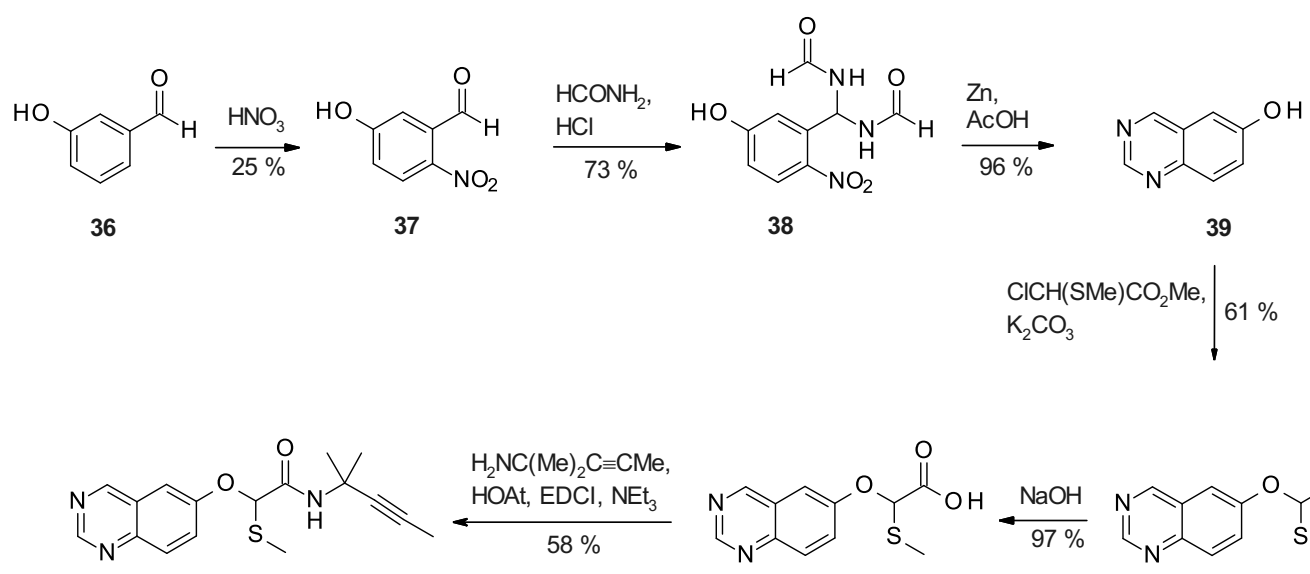

29
Scheme 7. Synthesis of the benzothiazole-based oomycetes fungicide 30 .<smiles>COc1cc(Cl)c2nc(N)sc2c1</smiles>

1. $\mathrm{NaNO}_{2}$,

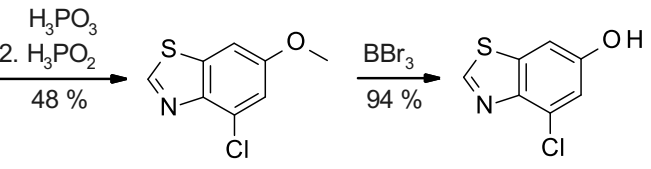

44

45

$$
\begin{aligned}
& \mathrm{ClCH}(\mathrm{SMe}) \mathrm{CO}_{2} \mathrm{Me}, \\
& \mathrm{K}_{2} \mathrm{CO}_{3}
\end{aligned} 81 \%
$$

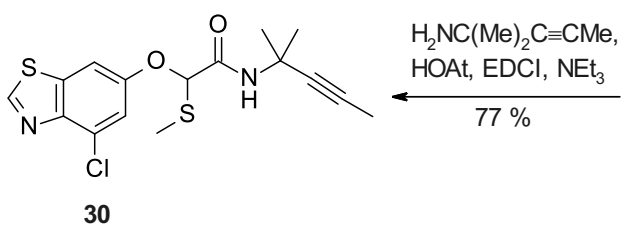<smiles>CSC(Oc1cc(Cl)c2ncsc2c1)C(=O)O</smiles>

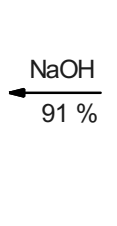

$$
{ }_{46}^{C l}
$$

soil-borne oomycetes phytopathogen Pythium ultimum, causal agent of the damping off / root rot disease, was never observed. A major reason for this spectrum gap is probably their lipophilicity, as a requirement for efficient Pythium control is a certain degree of systemicity, which means the ability to be transported inside the plant, which is facilitated by low partition coefficient $(\log P)$ and high water solubility values. Our search for a solution against all three economically important oomycetes pathogens Phytophthora infestans, Plasmopara viticola and Pythium ultimum triggered the design of close analogs of $\mathbf{2 8}$ with improved physico-chemical properties. As it turned out, the higher polarity of the quinazoline and benzothiazole analogs of $\mathbf{2 8}$, as demonstrated by their lower $\log \mathrm{P}$ values and the much higher water solubility, resulted in better translation from the in vitro Pythium assay to the in vivo test, especially the quinazolin-6-yloxyacetamide 29, which has an almost 1000 -fold increased water solubility compared to the quinoline analog 28, shows excellent efficacy against this devastating seedling-damaging disease (Table 3).[29]

\section{2010s: Inhibitors of Oxysterol-binding Protein}

At the end of the 2000s several patent applications of DuPont revealed a completely new structure type with powerful antioomycetes activity. These piperidinylthiazoles, of which the first product named oxathiapiprolin has recently reached the fungicide market, efficiently control oomycetes pathogens by blocking an oxysterol-binding protein. The bis-amide 48, which has been described by DuPont scientists as an important milestone in the discovery process of oxathiapiprolin, ${ }^{[40,41]}$ was, in the early $2010 \mathrm{~s}$, the starting point for our own derivatization. Because of the wellknown thiazole-pyridine bioisosterism, ${ }^{[42,43]}$ which is a validated technique in scaffold-hopping approaches of medicinal and agrochemical lead optimization, we thought its pyridyl analog 49, in which the ring nitrogen exactly keeps its position between the two ring carbon atoms bearing the carboxamide function and the piperidine, would be an interesting target. Two small conformationand exit vector-driven changes to this surprisingly inactive molecule, shifting the ring nitrogen to the other ortho-position of the carboxamide function and the removal of the methyl substituent from the amide nitrogen, turned $\mathbf{4 9}$ into the highly active analog 51. ${ }^{[4]}$ The reversion of an amide function is another well-known and successful scaffold-hopping manipulation, ${ }^{[45,46]}$ therefore we prepared the novel piperidinylthiazole derivative 50, in which the acid and amine linkage of the thiazole amide function in $\mathbf{4 8}$ have been switched. ${ }^{[46]}$ As the aminothiazole building block of $\mathbf{5 0}$ was perfectly suited for use in combinatorial chemistry, we found in a library with some conformationally preferred carboxylic acids the salicylamide $\mathbf{5 2}$ as an inverted amide with much better activity against Phytophthora infestans, Plasmopara viticola and also Pythium ultimum (Scheme 8). ${ }^{[47]}$

The synthesis of this reversed thiazole carboxamide $\mathbf{5 2}$ starts with the Pd-catalyzed Suzuki-Miyaura coupling of ethyl 2-bromothiazole-4-carboxylate (53) with $N$-Boc-1,2,5,6tetrahydropyridine-4-boronic acid pinacol ester, both of which are commercially available. Hydrogenation and BOC-deprotection of the resulting $\mathrm{C}-\mathrm{C}$ coupling product 54 deliver ethyl 2-(piperidin4-yl)thiazole-4-carboxylate (55). Amidation of the secondary amine with (5-methyl-3-trifluoromethylpyrazol-1-yl)acetyl chloride and subsequent saponification of the ester function lead to 56. This thiazole-4-carboxylic acid derivative is then converted into the corresponding hydroxamic acid $\mathbf{5 7}$, which under the conditions of the carbonyldiimdazole-mediated Lossen rearrangement ${ }^{[48]}$ directly delivers the corresponding 4-aminothiazole derivative 60. Carbonylimidazole is required in this transformation for two different purposes. First this reagent facilitates the forma- 
Table 3. Influence of the heterocycle on the physico-chemical properties and the fungicidal activity<smiles>[R]OC(SC)C(=O)NC(C)(C)C#CC</smiles>

\section{Pythium ultimum (damping-off)}

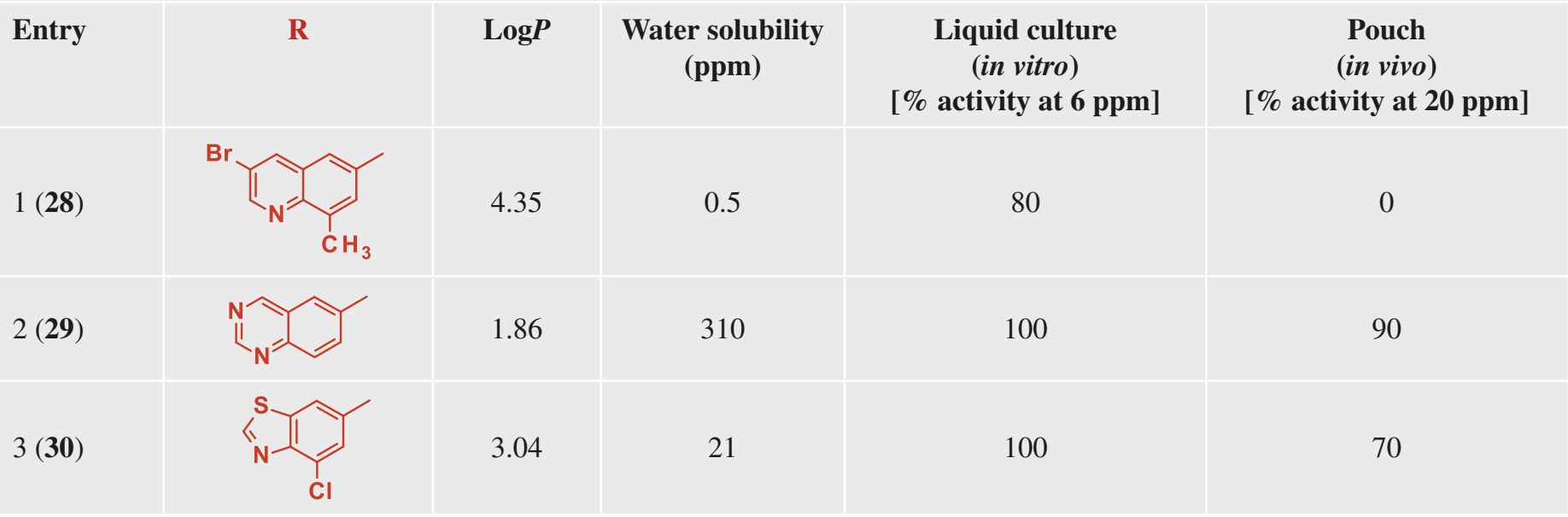<smiles>Cc1cc(C(F)(F)F)nn1CC(=O)N1CCC(c2nc(C(=O)N(C)C3CCCc4ccccc43)cs2)CC1</smiles>
the experimental oomycetes fungi cides $\mathbf{5 1}$ and $\mathbf{5 2}$.<smiles>Cc1cc(C(F)(F)F)nn1CC(=O)N1CCC(c2cccc(C(=O)N(C)C3CCCc4ccccc43)n2)CC1</smiles><smiles>Cc1cc(C(F)(F)F)nn1CC(=O)N1CCC(c2ccnc(C(=O)NC3CCCc4ccccc43)c2)CC1</smiles><smiles>C=C[C@H]1C=C[C@@H]1C(=O)N1CCC(c2nc(NC(=O)C3CCCc4ccccc43)cs2)CC1</smiles><smiles>Cc1cc(C(F)(F)F)nn1CC(=O)N1CCC(c2nc(NC(=O)c3cccc(Cl)c3O)cs2)CC1</smiles>

tion of the hydroxamic acid $\mathbf{5 7}$ under mild conditions. As soon as $\mathbf{5 7}$ is formed, additional carbonylimidazole causes its cyclization to the instable five-membered dioxazolone $\mathbf{5 8}$, which produces under loss of carbon dioxide the even more reactive isocyanate 59, which is trapped with 2-(trimethylsilyl)ethanol to a Teocprotected amine, from which $\mathbf{6 0}$ can be set free. Its amidation with 3 -chlorosalicylic acid under peptide coupling conditions affords the salicylamide $\mathbf{5 2}$ (Scheme 9). ${ }^{[47]}$

Also the synthesis of the piperidinylpyridine derivative 51 starts with a Suzuki-Miyaura coupling of $N$-Boc-1,2,5,6tetrahydropyridine-4-boronic acid pinacol ester, this time with 3-bromopicolinic acid (61) as reaction partner. Amidation of the resulting $\mathbf{6 2}$ with 1,2,3,4-tetrahydro-1-( $R$ )-naphthylamine under peptide coupling conditions afforded the tetraline amide $\mathbf{6 3}$. The same product can be obtained from the much cheaper starting material 2,4-dichloropyridine (64) by changing the order of the two steps. In the first of two consecutive palladium-catalyzed
C-C coupling reactions an aminocarbonylation with 1,2,3,4-tetrahydro-1- $(R)$-naphthylamine and carbon monoxide delivered the amide 65, which underwent Suzuki-Miyaura coupling with $N$-Boc-1,2,5,6-tetrahydropyridine-4-boronic acid pinacol ester to deliver the important building block $\mathbf{6 3}$ as well. After reduction of its tetrahydropyridine ring to the piperidine derivative 66 by catalytic hydrogenation, the hydrolytic cleavage of the Boc protecting group led to the secondary amine 67. Finally its amide coupling with (5-methyl-3-trifluoromethylpyrazol-1-yl)acetic acid delivered the desired target compound $\mathbf{5 1}$ (Scheme 10). ${ }^{[47]}$

Because of the already mentioned thiazole-pyridine bioisosteric relationship, our target molecule of choice has been the 1,3-disubstituted pyridine derivative 49 bearing the ring nitrogen exactly in the same position between the two ring carbon atoms bearing the carboxamide function and the piperidine ring as in the thiazole role model 48. To our big disappointment, 49 was completely inactive against major oomycetes diseases (entry 1, 
<smiles>CCOC(=O)c1csc(C(=O)OCC)c1</smiles>

Scheme 9. Synthesis of the oomycetes fungicide $\mathbf{5 2 .}$

Table 4). Modelling studies suggested that a disadvantageous electronic repulsion between the pyridine ring nitrogen and the carbonyl group and the desire for an internal hydrogen bonding between the pyridine nitrogen and the amide $\mathrm{NH}$ forces the amide function to flip into the other, inactive conformation. The solution was simply to shift the pyridine ring nitrogen into the other ortho-position of the carboxamide bearing ring carbon, resulting in a clear improvement of fungicidal activity (entry 2). In addition our model revealed that the removal of the methyl group at the amide nitrogen would further improve the efficacy, because this methyl group causes a sterical clash with the hydrogen atom in position 3 of the pyridine and hereby forces the carbonyl group of the amide function out of coplanarity with the pyridine ring, which seems to be unfavourable. Compound 51, the result of this second manipulation, fully controls Phytophthora infestans and Plasmopara viticola at the very low concentration of 2 ppm (entry 3, Table 4). ${ }^{[44]}$

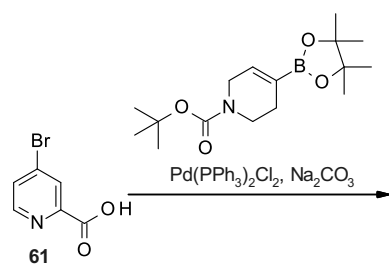<smiles>C=C/C(=C/C)C1=CCN(C(=O)OC(C)(C)C)CC1</smiles>

Scheme 10. Synthesis of the Oomycetes fungicide 51 .<smiles>Cc1cc(C(F)(F)F)nn1CC(=O)N1CCC(c2ccnc(C(=O)NC3CCCc4ccccc43)c2)CC1</smiles>

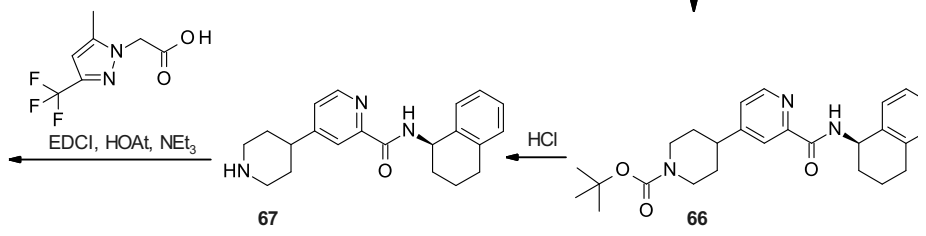




\section{Acknowledgements}

The author is extremely grateful to many of his chemist colleagues at Syngenta Crop Protection AG and its legacy companies, with whom he had the pleasure to collaborate on several different fungicide research projects during his career. Especially Andre Jeanguenat, Fred Cederbaum, Alain De Mesmaeker, Martin Zeller, Fiona Murphy Kessabi, Renaud Beaudegnies, Laura Quaranta, Stephan Trah, Raphael Dumeunier, Sarah Sulzer-Mosse, Guillaume Berthon, Martin Pouliot, Tomas Smejkal, Jayant Umarye, Atul Mahajan and Ravindra Sonawane made key contributions to the chemistry of the three presented mode of action classes and have deserved a big thank you. Torquil Fraser measured the reported physico-chemical properties, the biological testing was perfectly conducted by Hans-Joachim Kempf, Ronald Zeun, Gertrud Knauf-Beiter, Valeria Grasso and Mathias Blum, many thanks to all of them. In addition the author would like to thank his technicians Raymond Frey, Sandro Guelfi, Diana Grozinger and Armando Cicchetti for their productive execution of many different reactions from these three chemistry classes in his lab team. Especially Sandro Guelfi is praised here for 25 years of excellent synthesis support for the author. Finally I would like to express my gratitude to the Swiss Chemical Society for giving me the Senior Industrial Science Award.

Received: May 13, 2019

[1] U. Gisi, 'Chemical control of downy mildews' in 'Advances in Downy Mildew Research', Eds. P. T. N. Spencer-Phillips, U. Gisi, A. Lebeda, Kluwer: Dordrecht, 2002, pp 119-159.

[2] F. Schwinn, T. Staub, 'Phenylamides and other fungicides against oomycetes' in 'Modern Selective Fungicides', Ed. H. Lyr, Gustav Fischer: Jena, 1995, pp 323-346.

[3] J. M. Griffith, A. J. Davis, B. R. Grant, 'Target sites of fungicides to control oomycetes' in 'Target Sites of Fungicide Action', Ed. W. Köller, CRC Press: Boca Raton, 1992, pp 69-100.

[4] J. Kelly, 'The Graves are Walking. A History of the Great Irish Famine', Faber \& Faber: London, 2013.

[5] J. S. Donnelly, 'The Great Irish Potato Famine', Sutton Publishing: Stroud, 2005

[6] A. Huegel, 'Kriegsernährungswirtschaft Deutschlands während des Ersten und Zweiten Weltkrieges im Vergleich', Hartung-Gorre: Konstanz, 2003.

[7] T. Seitz, J. Benet-Buchholz, W. Etzel, M. Schindler, PflanzenschutzNachrichten Bayer 1999, 52, 5 .

[8] Y. Miyake, J. Sakai, M. Shibata, N. Yonekura, I. Miura, K. Kumakura, K. Nagayama, J. Pestic. Sci. 2005, 30, 390.

[9] D. A. Hunt, J. M: Lavanish, M. Asselin, M. Los, EP 493683 (American Cyanamid), Chem. Abstr. 1992, 117,145306.

[10] F. Cederbaum, A. De Mesmaeker, A. Jeanguenat, H.-J. Kempf, C. Lamberth, A. Schnyder, M. Zeller, R. Zeun, Chimia 2003, 57, 680.

Table 4. Influence of the piperidinylpyridine core on the fungicidal activity<smiles>Cc1cc(C(F)(F)F)nn1CC(=O)NC1CCCc2ccccc21</smiles>

Entry

$1(49)$<smiles>CN1CCC(c2cccc(C(=O)N(C)C)n2)CC1</smiles>

2
A<smiles>CN1CCC(c2ccnc(C(=O)N(C)C)c2)CC1</smiles><smiles>CCCCCNC(=O)c1cc(C2CCN(C)CC2)ccn1</smiles>

Phytophthora infestans (potato late blight) [\% activity at 2 ppm]
[11] C. Lamberth, A. Jeanguenat, F. Cederbaum, A. De Mesmaeker, M. Zeller, H.-J. Kempf, R. Zeun, Bioorg. Med. Chem. 2008, 16, 1531.

[12] R. G. Griffiths, J. Dancer, E. O'Neill, J. L. Harwood, New Phytologist 2003, 158,345 .

[13] O. Ort, U. Döller, W. Reissel, S. D. Lindell, T. L. Hough, D. J. Simpson, J. P. Chung, Pestic. Sci. 1997, 50, 331.

[14] C. Lamberth, F. Cederbaum, A. Jeanguenat, H.-J. Kempf, M. Zeller, R. Zeun, Pest Manag. Sci. 2006, 62, 446.

[15] U. Gisi, C. Lamberth, A. Mehl, T. Seitz, 'Carboxylic acid amide (CAA) fungicides', in 'Modern Crop Protection Compounds', 2nd Edition, Eds. W. Krämer, U. Schirmer, P. Jeschke, M. Witschel, Wiley-VCH: Weinheim, 2012, pp 807-830.

[16] M. Blum, M. Boehler, E. Randall, V. Young, M. Csukai, S. Kraus, F. Moulin, G. Scalliet, A. O. Avrova, S. C. Whisson, R. Fonne-Pfister, Mol. Plant Pathol. 2010, 11, 227.

[17] A. R. Kazemizadeh, A. Ramazani, Curr. Org. Chem. 2012, 16, 418.

[18] L. Banfi, R. Riva, 'The Passerini reaction' in 'Organic Reactions Vol. 65', Ed. L. E. Overman, Wiley: Hoboken, 2005, pp 1-140.

[19] D. Seebach, G. Adam, T. Gees, M. Schiess, W. Weigand, Chem. Ber. 1988 , $121,507$.

[20] M. Schiess, D. Seebach, Helv. Chim. Acta 1983, 66, 1618.

[21] C. Lamberth, H.-J. Kempf, M. Kriz, Pest Manag. Sci. 2007, 63, 57.

[22] R. V. Hoffman, N. K. Nayyar, J. Org. Chem. 1995, 60, 7043.

[23] R. Frey, S. G. Galbraith, S. Guelfi, C. Lamberth, M. Zeller, Synlett 2003, 1536.

[24] F. Cederbaum, C. Lamberth, C. Malan, F. Naud, F. Spindler, M. Studer, H.U. Blaser, Adv. Synth. Catal. 2004, 346, 842.

[25] C. Lamberth, F. Murphy-Kessabi, R. Beaudegnies, L. Quaranta, S. Trah, G. Berthon, F. Cederbaum, G. Knauf-Beiter, V. Grasso, S. Bieri, A. Corran, U. Thacker, Bioorg. Med. Chem. 2014, 22, 3922.

[26] S. Trah, C. Lamberth, Tetrahedron Lett. 2017, 58, 794.

[27] F. Murphy Kessabi, R. Beaudegnies, L. Quaranta, C. Lamberth, Tetrahedron Lett. 2016, 57, 5511 .

[28] F. Murphy Kessabi, L. Quaranta, R. Beaudegnies, C. Lamberth, Synlett 2016, 27, 1375.

[29] R. Beaudegnies, L. Quaranta, F. Murphy Kessabi, C. Lamberth, G. KnaufBeiter, T. Fraser, Bioorg. Med. Chem. 2016, 24, 444.

[30] A. Sharma, G. Saez-Calvo, N. Olieric, F. de Asis Balaguer, I. Barasoain, C. Lamberth, J. F. Diaz, M. O. Steinmetz, Int. J. Mol. Sci. 2017, 18, 1336.

[31] S. W. Tinsley, J. Am. Chem. Soc. 1955, 77, 4175.

[32] R. H. Baker, S. W. Tinsley, D. Butler, B. Riegel, J. Am. Chem. Soc. 1950, 72 , 393.

[33] C. Lamberth, F. Murphy Kessabi, R. Beaudegnies, L. Quaranta, S. Trah, G. Berthon, F. Cederbaum, T. Vettiger, C. S. Prasanna, Synlett 2014, 25, 858.

[34] C. A. Fetscher, M. T. Bogert, J. Org. Chem. 1939, 4, 71.

[35] M. T. Bogert, E. M. McColm, J. Am. Chem. Soc. 1927, 49, 2650

[36] N. P. Prajapati, R. H. Vekariya, M. A. Borad, H. D. Patel, RSC Adv. 2014, 4 , 60176.

[37] M. N. Bhoi, M. A. Borad, H. D. Patel, Synth. Commun. 2014, 44, 2427.

[38] D. G. Patil, M. R. Chedekel, J. Org. Chem. 1984, 49, 997.

[39] M. R. Chedekel, D. E. Sharp, G. A. Jeffery, Synth. Commun. 1980, 10, 167.

\section{Plasmopara viticola (grape downy mildew) [\% activity at 2 ppm]}


[40] R. J. Pasteris, M. A. Hanagan, J. J. Bisaha, B. L. Finkelstein, L. E. Hoffman, V. Gregory, J. L. Andreassi, J. A. Sweigard, B. A. Klyashchitsky, Y. T. Henry, R. A. Berger, Bioorg. Med. Chem. 2016, 24, 354.

[41] R. J. Pasteris, M. A. Hanagan, J. J. Bisaha, B. L. Finkelstein, L. E Hoffman, V. Gregory, C. P. Shepherd, J. L. Andreassi, J. A. Sweigard, B. A. Klyashchitsky, Y. T. Henry, R. A. Berger, 'The discovery of oxathiapiprolin: a new highly-active oomycete fungicide with a novel site of action' in 'Discovery and Synthesis of Crop Protection Products', Eds. P. Maienfisch, T. M. Stevenson, American Chemical Society: Washington, 2015, pp 149-161.

[42] Y.-M. Cui, Q.-Q. Huang, J. Xu, L.-L. Chen, J.-Y. Li, Q.-Z. Ye, J. Li, F.-J. Nan, Bioorg. Med. Chem. Lett. 2005, 15, 3732.

[43] P. Jeschke, 'Pyridine and thiazole-containing insecticides as potent agonists on insect nicotinic acetylcholine receptors' in 'Bioactive Heterocylic
Compound Classes', Eds. C. Lamberth, J. Dinges, Wiley-VCH: Weinheim, 2012, pp 209-223.

[44] S. Sulzer-Mosse, L. Quaranta, C. Lamberth, F. Cederbaum, M. Pouliot, J. Umarye, A. Mahajan, R. Sonawane, T. Smejkal, V. Grasso, M. Blum, S. Deller, M. Csukai, manuscript in preparation.

[45] C. Lamberth, Pest Manag. Sci. 2018, 74, 282.

[46] S. Subramanian, A. Costales, T. E. Williams, B. Levine, C. M. McBride, D. Poon, P. Amiri, P. A. Renhowe, C. M. Shafer, D. Stuart, J. Verhagen, S. Ramurthy, ACS Med. Chem. Lett. 2014, 5, 989.

[47] S. Sulzer-Mosse, F. Cederbaum, C. Lamberth, G. Berthon, J. Umarye, V. Grasso, A. Schlereth, M. Blum, R. Waldmeier, Bioorg. Med. Chem. 2015, 23, 2129.

[48] P. Dube, N. F. F. Nathel, M. Vetelino, M. Couturier, C. L. Aboussafy, S Pichette, M. L. Jorgensen, M. Hardink, Org. Lett. 2009, 11, 5622. 